Man and Nature

L'homme et la nature

\title{
Index - Volume I - X. 1982 -1992
}

by title

Volume 10, 1991

URI : https://id.erudit.org/iderudit/1012639ar

DOI : https://doi.org/10.7202/1012639ar

Aller au sommaire du numéro

Éditeur(s)

Canadian Society for Eighteenth-Century Studies / Société canadienne d'étude du dix-huitième siècle

ISSN

0824-3298 (imprimé)

1927-8810 (numérique)

Découvrir la revue

Citer ce document

(1991). Index - Volume I - X. 1982 -1992: by title. Man and Nature / L'homme et la nature, 10, 11-20. https://doi.org/10.7202/1012639ar

Copyright (c) Canadian Society for Eighteenth-Century Studies / Sociéte canadienne d'étude du dix-huitième siècle, 1991
Ce document est protégé par la loi sur le droit d'auteur. L'utilisation des services d’Érudit (y compris la reproduction) est assujettie à sa politique d'utilisation que vous pouvez consulter en ligne.

https://apropos.erudit.org/fr/usagers/politique-dutilisation/ 


\section{Index - Volume I - X 1982 - 1992}

BY TITLE

A Community of Exiles: The Quakers in 18th-Century Literature and Society, $\mathrm{X}, 93$

Leith, Hope

A la recherche du malade dans le Mariage de Figaro: quel(s) sens faut-il donner à l'objet-fauteuil? V, 15

Bérubé, Georges-L.

Adam Smith as Rhetorician, II, 61

Ross, Ian

'Allusion' in the Eighteenth Century: The Disinherited Critic, III, 23

Kinsley, William

An Early Hint of Miss Bridget's Affairs, With a Parallel Note on Mr. Allworthy, VI, 73

Brückmann, Patricia

An Examination of the Notes de Lecture of Louis de Bonald: At the Origins of the Ideology of the Radical Right in France, II, 93

Klinck, David M.

An Outline of Eighteenth-Century Russian Music, V, 165

Seaman, Gerald

Approche de l'hétérologie au siècle des Lumières, VII, 79

Berthiaume, Pierre

Aux armes et aux Arts! La société populaire et républicaine des arts et le Journal de Détournelle, $X, 47$

Hould, Claudette

Bacchus in Restoration and Eighteenth-Century Comedy: Wine as an Index of Generic Decline, VII, 179

Merrett, Robert James

Bentham as Revolutionary Social Scientist, VI, 115

Long, Douglas 
Bernard Bosanquet and the Development of Rousseau's Idea of the General Will, $\mathrm{X}, 179$

Sweet, William

Bibliographical Control of Eighteenth-Century French Canadiana, I, 131 Cameron, William J.

Bourgeois Morality and Aristocratic Libertinism in Comédie Larmoyante of La Chaussée, VIII, 9

Leith, Hope

Canonic Art: Pregnant Dilemmas in the Theory and Practice of Anton Raphael

Mengs, III, 113

Seerveld, Calvin

"Cher et illustre Roscius" - David Garrick's Influence on the Dramatic Theories of Diderot, VI, 21

Wilkshire, F.M.

Cinderella or Bluebeard: The Double Plot of Evelina, V, 85

Graham, Kenneth W.

Clarissa and the Concept of Tragedy: The Death of Lovelace, II, 37

Rinehart, Hollis

Conversations Containing Truth: Dialogues with Berkeley's Lying God, IX, 45

Cope, Kevin L.

Dante's Concept of Nobility and the Eighteenth-Century Tuscan Aristocracy: An

Unknown Study of the Convivio, V, 141

Pietropaolo, Domenico

David Hume and the Empiricist Theory of Law, IX, 33

Wein, Sheldon

David Williams and the Margaret Street Chapel, VIII, 99

Dybikowski, James

Deux confrontations du sauvage et du civilisé: les Dialogues de Lahontan et le

Supplément au voyage de Bougainville de Diderot, IX, 119

Coulet, Henri

Diderot entre les "Têtes Froides" et les "Enthousiastes", VI, 1

Mortier, Roland

Diderot vu par ses contemporains Italiens, V, 63

Davison, Rosena

Du jeu masqué aux Jeux de l'amour et du hasard: l'évolution du spectacle à l'italienne en France au xviiie siècle, V, 177

Trott, David

Du moraliste classique au moraliste des Lumières où la naissance des sciences humaines, V, 131

Mydlarski, $\mathrm{H}$. 
English Literature as Reflected in German Literature of the Eighteenth Century, DX, 91

Michelsen, Peter

Enlightened Despotism and the Resistance to Arbitrary Taxation in

Southwestern Germany after the Seven Years' War, V, 99

Liebel-Weckowicz, Helen

From Terror to the Terror. Changing Concepts of the Gothic in

Eighteenth-Century England, X, 165

Sabor, Peter

Gershom Carmichael and the Natural Jurisprudence Tradition in

Eighteenth-Century Scotland, I, 41

Moore, James and Michael Silverthorne

Gulliver Shifts for Himself, III, 47

Madoff, Mark

Hume's Tu Quoque: Newtonianism and the Rationality of the Causal Principle, VII, 131

Haynes, Michael

Hume's Causal Account of the Self, IX, 23

Brett, Nathan

Hume: Justice as Property, VI, 55

Brett, Nathan

Ignatius Fessler's Attila: An Eighteenth-Century Historical Novelist's Reply to

Schiller's Question "Was heisst und zu welchem Ende studiert man

Universalgeschichte?" II, 83

DeLong, Linwood

J.M.R. Lenz and the Humanizing Role of Literature, DX, 109

Diffey, Norman R.

J.M.R. Lenz as Theologian, II, 75

Pope, Timothy

Jacques le fataliste: Narrative Structure and New Physics, II, 15

Highnam, David

Jonathan Richardson's 'Hymn to God', VIII, 81

Gibson-Wood, Carol

L'égalité au dix-huitième siècle: l'importance de l'aequanimitas, VII, 117

Marcil-Lacoste, Louise

L'Emergence de la notion d'intérêt dans l'esthétique des Lumières,

VI, 193

Moser-Verrey, Monique 
L'Érudition et la fonction du savoir au $\mathrm{XVW}^{\mathbf{e}}$ siècle: Pierre Potier chez les Hurons du Détroit, I, 165

Toupin, Robert

L'Etrange don du Marquis de Sade à la Révolution et à l'Empire: son théâtre, VI, 209

Silver, Marie-France

'L'honnêteté a demi-nue,' ou la part des femmes, VII, 71

Poupeney-Hart, Catherine

La Grèce dans le roman français de l'époque révolutionnaire: Le voyage du jeune Anacharsis en Grèce au IVe siècle avant l'ère vulgaire,

$\mathrm{IX}, 145$

Silver, Marie-France

La Philosophie politique de Kant, I, 81

Crombie, James

La Physiologie des Lumières, II, 139

Duchesneau, François

La question du pouvoir dans le thêâtre français de deux époques: 1589 et 1789, IX, 133

Annandale, Eric $\mathrm{T}$.

'La Reine fantasque' de Jean-Jacques Rousseau: une subversion littéraire, X, 159

Runte, Roseann

La Rhétorique amoureuse dans Les Égarements du coeur et de l'esprit, I, 21

Terrasse, Jean

La Valeur sémantique du Nord, du Midi, de l'Orient, et de l'Occident chez Voltaire, VI, 45

Piechura, Krystyna

La vie intellectuelle et les activités culturelles à la Forteresse de Louisbourg 1713-1758, IV, 129

Lavoie, Laurent

La Visée historiographique de Charlevoix d'aprés ses “Liste et examen des auteurs consultés", I, 153

Ouellet, Réal

Lait Républicain: Les Conventionnels et la Fonction Sociale de la Maternité, X, 39 Grenon, Michel

Lavoisier, Priestley, and the Philosophes: Epistemic and Linguistic Dimensions to the Chemical Revolution, VIII, 91

McEvoy, John G. 
Le concept de souveraineté du peuple: de Rousseau à la Déclaration des droits de ' $93, X, 13$

Boulad-Ayoub, Josiane

Le masque et l'éventail, VII, 53

Gobin, Pierre

Le principe de liberté et les contraintes institutionnelles envisagées dans les Cinq mémoires sur l'instruction publique de Condorcet, $\mathrm{X}, 133$

Niklaus, Robert

Le Retable de Saint-Augustin-de-Desmaures: une oeuvre d'architecture intérieure du XVIII ${ }^{e}$ siècle (1746) transplantée dans un ensemble plus tardif, I, 175

Gobeil-Trudeau, Madeleine

Le Roman du XVIIIe siècle: Signification de l'encadrement, V, 1

Amprimoz, Alexandre

Le Siècle de Lumières face à la torture, VI, 173

Clark, E. Roger

Le supplice de Servet. Voltaire historien et les droits de la personne, $\mathrm{X}, 113$

MacLean, James Forsythe

Le Troglodyte image fictive du Sauvage canadien, V, 191

Viselli, Santé A.

Legislating Virtue: John Brown's Scheme for National Education, DX, 69

Crimmins, James $\mathrm{E}$.

Les débuts de la Maçonnerie au Québec, VII, 195

De Lagrave, Jean-Paul

Les Fantasmes de l'argent dans l'Histoire du chevalier des Grieux et de Manon

Lescaut, I, 1

Joly, Raymond

Les femmes et la diffusion des Lumières, VII, 23

Didier, Béatrice

Les fondements du savoir dans la pensée moraliste des Lumières, VII, 141 Mydlarski, Henri

Les Lumières en Amérique espagnole: Plan d'études pour la Colombie coloniale de Moreno y Escandon, 1774-1779, II, 121

Loncol, Jean-Marie

Les Moralistes et la Révolution, VI, 181

Mydlarski, Henri

Liberation from Tutelage? A Sketch of Women's Education in 18th Century

Germany, VII, 13

Fell, Christa 
Liberté, libertinage et despotisme chez Mirabeau, VIII, 17 Viselli, Santé A.

Libertinage et Révolution: Les Romans du Marquis de Sade, VIII, 129 Silver, Marie-France

Libertinage, folie, utopie, liberté: les Amours du Chevalier de Faublas, VIII, 49

Gobin, Pierre

Liberty is My Due: Don Juan and Free Thought in the ancien régime, VIII, 1

Bevis, Richard W.

Lillo and More in France: English Influences on the Dramatic Theory of Diderot, $\mathrm{V}, 201$

Wilkshire, F.M.

Marivaux's 'Libertinage d'Idées' in Le Spectateur Français, VIII, 73

Chadbourne, Richard M.

Matter, Mind, and Active Principles in Mid-Eighteenth-Century British

Physiology, IV, 17

Wright, John P.

Mme Bégon, a Colonial Salon Hostess, III, 89

Rubinger, Catherine

Modern Isms and the Lovejovian Universe, V, 119

Molitor, Helen O.

Musical Rhetoric and Other Symbols of Communication in Bach's Organ Music, III, 131

Kloppers, Jacobus

Naissance de l'opinion publique, VII, 1

Sgard, Jean

Natural Law and the Scottish Enlightenment, IV, 47

Haakonssen, Knud

New Trends in the Form and Function of the Dénouement: German

Empfindsamkeit and Sturm und Drang, III, 101

Wittmann, Anna

Peuplement colonisateur au XVIIIe siècle dans le gouvernement du Québec, II, 127

Mathieu, Jacques, François Béland, Michèle Jean, Jeannette Larouche, Renald Lessard

Physiological Mechanism from Boerhaave to Haller, I, 209

Duchesneau, François

Planning Space for the Masses in France 1789-1799, VI, 225

Leith, James A. 
Polemical Intent and Rhetorical Style in d'Alembert's Éloges historiques, I, 31 Essar, Dennis F.

Pour un théâtre de la présence: Diderot du théâtre au roman, II, 27

Scott, Anne

Problèmes du monde hispanique au XVII ${ }^{e}$ siècle: les Comuneros de

Nouvelle-Grenade et l'oeuvre de Francisco Antonio Moreno y Escandón

(1781), I, 103

Loncol, Jean-Marie

Prophetic Discourse and the Voice of Protest: The Vindication of Anne

Wentworth, VIII, 29

Camden, Vera J.

Public and Private in Cowper's The Task, $\mathrm{X}, 1$

Baird, John

Reflections on a Remarkable Performance of Hamlet: A Reexamination of the

Hamlet Scene in Goethe's Wilhelm Meisters Lehrjahre, V, 73

Delong, Linwood R.

Reid and the Rights of Man, IV, 81

Dalgarno, Melvin

Répétition et instabilité: la signification de Zadig, III, 63

Runte, Roseann

Revolution, Reaction and the Expropriation of Popular Culture: Hannah More's

Cheap Repository, VI, 147

Kelly, Gary

Rhétorique Féministe et Liberté Personnelle, VIII, 107

Cragg, Olga B.

Robinson Crusoe, Friday, and the Noble Savage: The Illustrations of the Rescue of Friday in the Eighteenth Century, V, 29

Blewett, David

Rousseau Pédagogue Avant Emile: Le Problème de L'Autorité, X, 199

Terrasse, Jean

Sancte Socrates: Scottish Reflections on Obedience and Resistance, I, 65

Stewart-Robertson, J.C.

Shakespeare and Eighteenth-Century German Poetics, IV, 171

Schwarz, Hans-Günther

'So proper for that constant pocket use': Posthumous Editions of Pope's Works (1751-1754), VI, 81

Nichol, Donald W.

'Storms of Sorrow': The Poetry of Helen Maria Williams, X, 77

Kennedy, Deborah 
Textes et réécritures de textes: le cas des Fêtes grecques et romaines de Louis

Fuzelier, III, 77

Trott, David

The Art of Medicine in Pre-Loyalist New Brunswick, IV, 139

Mackay, John

The British Discovery of Sicily: Western Greeks and Liberty, VIII, 119

Retzleff, Garry

The Camera Obscura or the Optics of Realism, VIII, 63

Schwarz, Hans-Günther

The Canonized Forefathers and the Household of Man: Burke's Reflections on

the Revolution in France and Wordsworth's 'Michael', X, 121

McWhir, Anne

The Competition for American Seamen during the War of 1739-1748,

I, 119

Swanson, Carl E.

The Complete Female: Musical 'Accomplishment' in the Late Eighteenth

Century, VIII, 39

Rempel, Ursula M.

The German Enlightenment: Literaturgeschichte or Theologiegeschichte? V, 153 Pope, Timothy

The Individual and the Collective in Eighteenth-Century Language Theory, $X, 57$ Hudson, Nicholas

The Influence of the New Sciences on Daniel Defoe's Habit of Mind, VII, 167 Vickers, Ilse

The Magic Flute and Viennese Opinion, VI, 161

MacPherson, Jay

The Massachusetts Superior Court and the American Revolution: The

Professionalization of a Judicial Elite, 1740-1775, I, 109

Russell, Peter E.

The Physico-Theological Epic in the Later Eighteenth Century, II, 49

Sampson, H. Grant

The Poet and Affairs of State in Johnson's Lives of the Poets, VI, 93

Erskine-Hill, Howard

The Revolt of the Wuerttemberg Estates, 1764-1770, II, 109

Liebel-Weckowitz, Helen P.

The Rhetoric of Grace in Jonathan Edwards' Personal Narrative, IV, 109

Martin, John Stephen 
The Rights of the Individual in Habsburg Civil Law: Joseph II and the Illegitimate, X, 105

Levy, Miriam J.

The Role of Providence in Rousseau's Revelation on the Road to Vincennes, VI, 35

Rosenberg, Aubrey

"The Romance of Real Life": Autobiography in Rousseau and William Godwin, I, 93

Kelly, Gary

The Uses of Shandeanism: The Theatre Criticism of Charles Este, $X, 31$

Copeland, Nancy

The 'Canada-Guadeloupe' Debate and the Origins of the Grenville Programme for America, $\mathrm{V}, 51$

Bumsted, J.M.

This Pestiferous Reading: The Social Basis of Reaction against the Novel in Late Eighteenth- and Early Nineteenth-Century Britain,

IV, 183

Kelly, Gary

Thomas Reid's Critique of Joseph Priestley: Context and Chronology, IV, 29 Wood, Paul B.

Thomas Warton's Gothic Sensibility, X, 147

Rielly, Edward J.

Those Damn Sacred Hymns': Some Problems with the Ontology of 'Text', IX, 57 Arnold, Richard

Those Scotch Imposters and their Cabal": Ossian and the Scottish

Enlightenment, I, 55

Sher, Richard B.

To Keep Them in Proper Subjection': Jeffrey Amherst and the Indians, IV, 155 Farrell, David R.

Towards an Histrionic Aesthetics: Diderot's Paradoxes as Pre-text for Romantic Irony, VII, 149

Spencer, Judith

Un Philosophe contre la cour: le marquis d'Argenson et l'échec de la réforme politique sous Louis $\mathrm{XV}, \mathrm{X}, 67$

Johnson, Neal

Vampiromania in the Eighteenth Century: The Other Side of Enlightenment, III, 1 Dimic, Milan V.

Vico's Humanity, IX, 1 Mooney, Michael 
Vital Forces and Vital Laws in Eighteenth-Century French Physiology, IV, 1

Haigh, Elizabeth

Voltaire et La Mort de César, I, 15

Bérubé, Georges-L.

Voltaire revu et corrigé par la Révolution Française: Le cas de La mort de César, X, 209

Usandivaras-Mili, Muriel

Voltaire's Reaction to Maupertuis's Lettre sur le progrès des sciences, VII, 159

Smith, Margarete G.

What Represents in a Representation? A Question Concerning Michel Foucault's

"Age Classique", II, 1

Creech, James

William Blake and Westminster Abbey, I, 185

Reisner, M.E.

Women Artists in Eighteenth-Century France, I, 199

Evans, Howard V. and Charlotte B.

Women, Allegory, and the French Revolution: The Case of Armed Liberty, IV, 95 Cameron, Vivian

Writing Boswell: Form, Text, and Identity in the London Joumal, X, 227

Zeitz, Lisa M. 